\title{
Differential Desensitization of Responses Mediated by Presynaptic and Postsynaptic $A_{1}$ Adenosine Receptors
}

\author{
Jonathon P. Wetherington and Nevin A. Lambert \\ Department of Pharmacology and Toxicology, Medical College of Georgia, and Medical Research Service, Augusta \\ Veterans Affairs Medical Center, Augusta, Georgia 30912
}

G-protein-coupled receptors (GPCRs) often desensitize during continuous activation, but it is not known whether desensitization is influenced by subcellular location. In hippocampal neurons, activation of adenosine $A_{1}$ receptors (A1Rs) or $G A B A_{B}$ receptors on synaptic terminals inhibits neurotransmitter release, whereas activation of the same receptors on cell bodies and dendrites decreases excitability by activating inwardly rectifying potassium (GIRK) channels. Here we report that responses mediated by presynaptic A1Rs desensitize more slowly than responses mediated by postsynaptic (somatodendritic) A1Rs in cultured neurons. Agonist treatment for $2 \mathrm{hr}$ has no effect on adenosine-induced presynaptic inhibition, whereas such treatment nearly abolishes adenosine-induced activation of postsynaptic GIRK channels. Agonist treatment for longer periods ( $>12 \mathrm{hr}$ ) eventually desensitizes A1R-mediated presynaptic inhibition. Presynaptic and postsynaptic responses both recover from desensitization after agonist removal, but recovery

Many neurotransmitters signal by binding to G-protein-coupled receptors (GPCRs). In neurons, the ultimate effect of GPCR activation often depends on the location of the receptors on the cell surface. For example, several GPCRs couple to pertussis toxin-sensitive G-proteins to inhibit adenylate cyclase, inhibit voltage-gated calcium channels, and activate inwardly rectifying potassium (GIRK) channels. Activation of these receptors on synaptic terminals inhibits neurotransmitter release, whereas activation of these receptors on cell bodies and dendrites decreases excitability by opening GIRK channels. Some types of these receptors are selectively expressed on presynaptic (axon terminal) or postsynaptic (somatodendritic) domains (Stowell and Craig, 1999; Jolimay et al., 2000), but other types are present at both locations. In the hippocampus, the latter class includes adenosine $A_{1}$ receptors (A1Rs) and $\mathrm{GABA}_{\mathrm{B}}$ receptors (GABABRs).

When GPCRs are persistently activated, the resulting response often diminishes over time as a result of receptor desensitization. A common mechanism is responsible for desensitization of many GPCRs, the best-studied example being the $\beta_{2}$ adrenoreceptor. Active GPCRs are phosphorylated by G-protein receptor kinases (GRKs) (Benovic et al., 1986; Pitcher et al., 1998), which uncou-

\footnotetext{
Received Oct. 9, 2001; revised Nov. 29, 2001; accepted Nov. 30, 2001.

This work was supported by National Institutes of Health Grant NS 36455 and a Veterans Affairs Merit Award. We thank John Dempster for providing data acquisition software (WinWCP).

Correspondence should be addressed to Nevin A. Lambert, Department of Pharmacology and Toxicology, Medical College of Georgia, Augusta, GA 309122300. E-mail: nlambert@mail.mcg.edu.

Copyright (C) 2002 Society for Neuroscience $\quad 0270-6474 / 02 / 221248-08 \$ 15.00 / 0$
}

of presynaptic inhibition requires more time. Desensitization of postsynaptic responses apparently occurs at the level of the receptor, because postsynaptic G-proteins and GIRK channels appear to be fully functional. Inhibition of voltage-gated calcium channels by postsynaptic A1Rs also desensitizes rapidly, although this desensitization is less complete than is observed for activation of postsynaptic GIRK channels. Comparison of concentration-response curves for presynaptic and postsynaptic responses suggests that a receptor reserve exists for presynaptic inhibition, but that the magnitude of this reserve is insufficient to account for the absence of presynaptic desensitization after brief agonist exposure. These results suggest that agonist-induced desensitization of responses mediated by neuronal GPCRs may depend on the subcellular location of the receptors.

Key words: desensitization; downregulation; GPCR; presynaptic inhibition; GIRK; adenosine; $G A B A_{B}$

ples receptors from G-proteins and promotes binding of arrestins (Lohse et al., 1990). Arrestin-bound GPCRs are physically uncoupled from G-proteins and are targeted for endocytosis (Carman and Benovic, 1998; Ferguson and Caron, 1998; Lefkowitz, 1998; Ferguson, 2001). Internalization of GPCRs prevents further transmembrane signaling and is sometimes a prelude to receptor downregulation, during which the total amount of receptor protein in a cell decreases (Tsao et al., 2001). Desensitization of GPCRs in neurons is thought to underlie tolerance to centrally active drugs (Bohn et al., 2000) and may also be involved in the development of drug dependence. It is therefore important to fully understand the mechanisms of GPCR desensitization in neurons.

Relatively few studies have investigated GPCR desensitization in polarized cells in which receptor function can be measured in different subcellular domains. Therefore, little is known about how receptor location influences desensitization. We have addressed this question by studying the effects of chronic agonist application on responses mediated by presynaptic and postsynaptic A1Rs (Proctor and Dunwiddie, 1987). We find that A1Rs in both locations desensitize after chronic agonist application, but presynaptic receptors desensitize much more slowly than postsynaptic receptors. These results suggest that the mechanisms of GPCR desensitization may differ in different regions of individual cells.

\section{MATERIALS AND METHODS}

Cell culture and chronic drug application. Hippocampal neurons were grown on collagen/polylysine microislands essentially as described (Segal and Furshpan, 1990; Bekkers and Stevens, 1991). Hippocampi were 
dissected from newborn rats and digested with papain $(\sim 25 \mathrm{U} / \mathrm{ml}$; Worthington, Freehold, NJ). After dissociation, $5 \times 10^{4}$ neurons were plated in $35 \mathrm{~mm}$ dishes that had been coated with $0.15 \%$ agarose (Sigma, St. Louis, MO) and then sprayed with a 1:5 (v/v) mixture of rat tail collagen $(3.6 \mathrm{mg} / \mathrm{ml})$ and poly-D-lysine $(0.5 \mathrm{mg} / \mathrm{ml}$; both from Becton Dickinson, Mountain View, CA). Growth medium contained minimal essential medium (MEM) supplemented with B-27 (Invitrogen, Gaithersburg, MD), serum extender (Becton Dickinson), 5\% defined FBS (Hyclone, Logan, UT), 0.6\% glucose, $1 \mathrm{~mm}$ pyruvate, and $0.5 \mathrm{~mm}$ glutamine. Neurons were treated chronically with drugs (or vehicle) by adding sterile-filtered stock solutions directly to culture dishes, which were then returned to the incubator $\left(37^{\circ} \mathrm{C}, 5 \% \mathrm{CO}_{2}\right)$ for the appropriate time. Recordings were made $<1 \mathrm{hr}$ after dishes were removed from the incubator and washed with drug-free external solution.

Recording solutions and electrophysiology. Whole-cell patch-clamp recordings were made from isolated (one neuron per microisland) neurons. For recordings of synaptic currents and GIRK currents, patch electrodes were filled with a solution containing (in $\mathrm{mM}$ ): $140 \mathrm{~K}$-gluconate, $5 \mathrm{KCl}$, 0.2 EGTA, 10 HEPES, $3 \mathrm{MgATP}, 0.3 \mathrm{Na}_{2} \mathrm{GTP}$ (pH 7.2, $295 \mathrm{mOsm} / \mathrm{kg}$ $\mathrm{H}_{2} \mathrm{O}$ ). The external solution for synaptic recordings contained (in $\mathrm{mM}$ ): $150 \mathrm{NaCl}, 2.5 \mathrm{KCl}, 10$ HEPES, 10 glucose, $1.5 \mathrm{CaCl}_{2}, 2.5 \mathrm{MgCl}_{2}$ (pH 7.2, $\sim 310 \mathrm{mOsm} / \mathrm{kg} \mathrm{H}_{2} \mathrm{O}$ ). The external solution for simultaneous recording of GIRK and synaptic currents (see Fig. 8) was the same as above, with $\mathrm{KCl}$ increased to $6 \mathrm{~mm}$. The external solution for the remaining GIRK current recordings was the same, with $\mathrm{KCl}$ increased to $30 \mathrm{mM}, \mathrm{NaCl}$ reduced to $122.5 \mathrm{~mm}$, and $0.5 \mu \mathrm{M}$ tetrodotoxin (TTX). For recordings of calcium currents, patch electrodes were filled with a solution containing (in mM): $100 \mathrm{CsCl}, 40$ tetraethylammonium-Cl, 0.2 EGTA, 10 HEPES, 3 MgATP, $0.3 \mathrm{Na}_{2} \mathrm{GTP}\left(\mathrm{pH} 7.2, \sim 295 \mathrm{mOsm} / \mathrm{kg} \mathrm{H}_{2} \mathrm{O}\right.$ ), and the external solution contained (in $\mathrm{mM}$ ): $150 \mathrm{NaCl}, 2.5 \mathrm{KCl}, 10$ HEPES, 10 glucose, 3 $\mathrm{CaCl}_{2}, 2 \mathrm{MgCl}_{2}, 0.2 \mathrm{BaCl}_{2}$ and (in $\mu \mathrm{M}$ ): $0.5 \mathrm{TTX}, 10$ 6,7-dinitroquinoxaline-2,3-dione, and $10 \mathrm{D}(-)$-2-amino-5-phosphonopentanoic acid ( $\mathrm{pH} 7.2$, $\sim 310 \mathrm{mOsm} / \mathrm{kg} \mathrm{H}_{2} \mathrm{O}$ ). All recordings were made at room temperature. Series resistance was minimized by briefly applying positive pressure after patch rupture and was compensated using the amplifier. For synaptic recordings, neurons were held at $-60 \mathrm{mV}$ and depolarized above $0 \mathrm{mV}$ with $2 \mathrm{msec}$ square commands every $5 \mathrm{sec}$. For recordings of postsynaptic GIRK currents, the membrane potential was ramped from -100 to -10 $\mathrm{mV}$ at a rate of $0.18 \mathrm{mV} / \mathrm{msec}$ or stepped to $-100 \mathrm{mV}$ (see Fig. 8). For calcium current recordings, neurons were held at $-80 \mathrm{mV}$ and stepped to $0 \mathrm{mV}$ for $40 \mathrm{msec}$. Currents evoked by this protocol were subjected to $\mathrm{P} / 4$ leak subtraction before analysis. Currents were digitized and recorded with a multif unction I/O board and WinWCP software (provided by Dr. J. Dempster, Strathclyde University, Glasgow). Drugs were applied during recordings via a fused silica tube (inner diameter, $200 \mu \mathrm{m}$ ) connected to multiple reservoirs. Numerical values, plots, and bar graphs are expressed as mean \pm SEM, and statistical comparisons were made using Student's unpaired $t$ test or ANOVA. Concentration-response curves were fitted to the Hill equation, $Y=M\left(X^{\mathrm{n}} /\left(X^{\mathrm{n}}+K^{\mathrm{n}}\right)\right.$, where $M$ is the maximal response, $X$ is the concentration of drug, $n$ is a slope factor, and $K$ is the concentration at half the maximal effect $\left(\mathrm{EC}_{50}\right) \cdot \mathrm{EC}_{50}$ values reported in the text were derived from these fits.

\section{RESULTS}

\section{Differential regulation of presynaptic and postsynaptic adenosine responses}

Postnatal hippocampal neurons were grown on substrate microislands such that the cells formed synapses (autapses) onto themselves (Segal and Furshpan, 1990). After 14-18 d in vitro, transient depolarization of these cells in whole-cell voltage-clamp mode evoked unclamped action potentials, which in turn evoked EPSCs (Bekkers and Stevens, 1991). In control neurons, application of saturating concentrations of either adenosine $(100 \mu \mathrm{M})$ or the selective GABABR agonist baclofen $(50 \mu \mathrm{M})$ decreased the amplitude of EPSCs by $\sim 80 \%$ (Fig. $1 A$ ). In control experiments (data not shown) using selective agonists and antagonists, we verified that depression of EPSCs by adenosine or baclofen was mediated by activation of A1Rs and GABABRs, respectively. The adenosine response was blocked by the selective A1R antagonist cyclopentyldipropylxanthine (DPCPX) (1 $\mu \mathrm{M}$; data not shown), whereas the baclofen response was blocked by the selec-

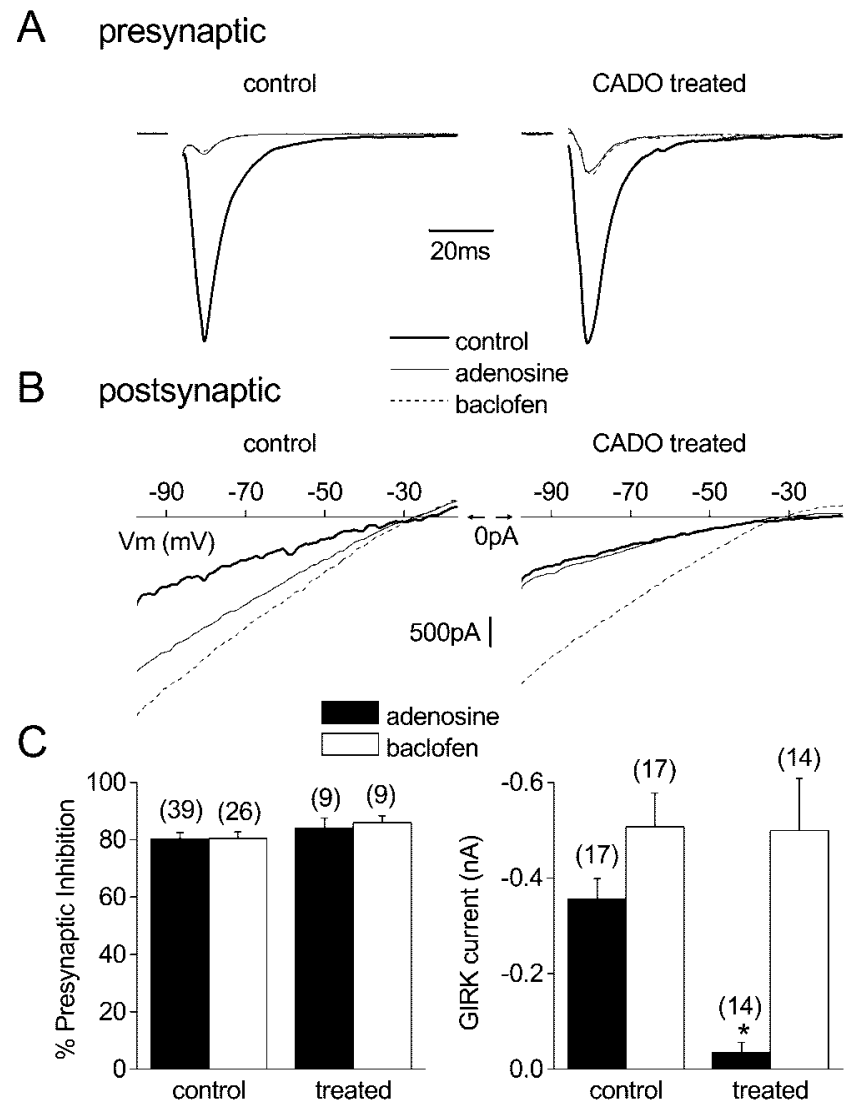

Figure 1. Agonist treatment for $4 \mathrm{hr}$ desensitizes postsynaptic but not presynaptic adenosine responses. $A$, EPSCs (autaptic) recorded from cultured hippocampal neurons are shown after treatment with vehicle (control) or $20 \mu \mathrm{M}$ 2-chloroadenosine (CADO treated). In both cases activation of adenosine $A_{1}$ receptors with $100 \mu \mathrm{M}$ adenosine or $\mathrm{GABA}_{\mathrm{B}}$ receptors with $50 \mu \mathrm{M}$ baclofen produces robust presynaptic inhibition. These examples are shown normalized to the control current and scaled proportionally. $B$, Current-voltage relationships recorded from vehicle- or CADO-treated neurons in response to a voltage ramp command (from -100 to $-10 \mathrm{mV} ; 0.18 \mathrm{mV} / \mathrm{msec}$ ) in the presence of $30 \mathrm{~mm}$ external $\mathrm{K}^{+}$ and tetrodotoxin $(0.5 \mu \mathrm{M})$. In the control neuron, application of either adenosine or baclofen induced a robust inwardly rectifying current (GIRK current). In the CADO-treated neuron, baclofen induced a robust GIRK current, whereas the adenosine-induced current was greatly diminished. In these panels, the voltage scale is located at 0 pA. $C$, Summary of all experiments examining presynaptic inhibition and postsynaptic GIRK currents (at $-60 \mathrm{mV}$ ) in vehicle-treated (control) and CADO-treated (treated) neurons. Only adenosine-induced GIRK currents were significantly reduced $(* p<0.01)$ compared with responses in vehicle-treated neurons. Error bars represent the mean $\pm \mathrm{SE}$; the number of experiments $(n)$ is in parentheses.

tive GABABR antagonist CGP 55845A (1 $\mu \mathrm{M}$; data not shown). A number of previous studies have shown that A1Rs and GABABRs inhibit EPSCs in hippocampal neurons by decreasing neurotransmitter release, and both receptors couple to effectors via pertussis toxin (PTX)-sensitive G-proteins (Dunwiddie and Haas, 1985; Scholz and Miller, 1991a,b; Thompson and Gahwiler, 1992; Thompson et al., 1992, 1993).

In addition to these presynaptic effects, application of either adenosine or baclofen activated a postsynaptic current with properties characteristic of currents mediated by GIRK channels (Jan and Jan, 1997; Ehrengruber et al., 1998). During recordings of EPSCs, this was evident as a small outward shift in holding current. In external solution containing $30 \mathrm{mM} \mathrm{K}^{+}$, application of 

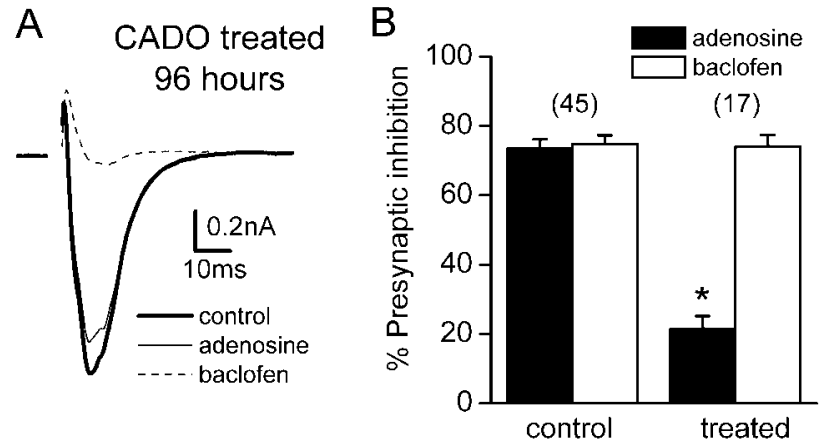

Figure 2. Agonist treatment for $>12 \mathrm{hr}$ desensitizes presynaptic adenosine responses. $A$, Averaged EPSCs recorded from a neuron treated with $20 \mu \mathrm{M}$ CADO for $96 \mathrm{hr}$ under control conditions, in the presence of 100 $\mu \mathrm{M}$ adenosine, and in the presence of $50 \mu \mathrm{M}$ baclofen are shown superimposed. $B$, Grouped data from control cells and cells treated with CADO for $48 \mathrm{hr}$. Adenosine-induced presynaptic inhibition was significantly reduced $(p<0.01)$, whereas baclofen-induced presynaptic inhibition in the same cells was not changed. Error bars represent the mean \pm $\mathrm{SE}$; the number of experiments $(n)$ is in parentheses.

either drug reversibly induced an inwardly rectifying current that reversed polarity near the calculated $\mathrm{K}^{+}$equilibrium potential of $-39 \mathrm{mV}$ (Fig. 1B). Again, control experiments using selective antagonists indicated that adenosine and baclofen effects were mediated by A1Rs and GABABRs, respectively (see above; data not shown). We used this system to study the effect of chronic agonist activation on responses mediated by presynaptic and postsynaptic A1Rs. Because A1Rs and GABABRs are thought to couple to the same downstream signaling molecules (Nicoll et al., 1990), we used responses mediated by presynaptic and postsynaptic GABABRs to assess the function of G-proteins and effector molecules after chronic A1R activation.

In the first series of experiments, neurons were treated with either $20 \mu \mathrm{M}$ 2-chloroadenosine (CADO), a poorly hydrolyzable analog of adenosine, or vehicle at $37^{\circ} \mathrm{C}$ for $4 \mathrm{hr}$. After CADO treatment, presynaptic inhibition mediated by acute activation of either A1Rs (100 $\mu \mathrm{M}$ adenosine) or GABABRs (50 $\mu \mathrm{M}$ baclofen) was unaltered (Fig. 1A). In contrast, activation of postsynaptic GIRK channels by A1Rs was dramatically reduced (Fig. 1B). Adenosine-induced currents at $-60 \mathrm{mV}\left(30 \mathrm{~mm}\right.$ external $\left.\mathrm{K}^{+}\right)$in vehicle-treated control cells were $-356 \pm 43 \mathrm{pA}(n=17)$, whereas these currents were $-35 \pm 21 \mathrm{pA}$ in CADO-treated neurons $(n=14 ; p<0.01)$. This desensitization was homologous, because baclofen-induced GIRK currents in the same neurons were not different from those induced in control neurons $(p>$ 0.05) (Fig. 1C).

These results indicated that responses mediated by presynaptic and postsynaptic A1Rs were differentially regulated by chronic agonist application. To determine whether presynaptic inhibition mediated by A1Rs was completely refractory to agonist-induced regulation, we extended the duration of agonist treatment. As shown in Figure 2, longer exposures to CADO substantially diminished presynaptic inhibition. For example, after treatment with CADO for $48 \mathrm{hr}$, presynaptic inhibition induced by $100 \mu \mathrm{M}$ adenosine was reduced to $21 \pm 4 \%$ ( $n=17 ; p<0.01$ compared with controls). As was the case with postsynaptic responses, baclofen-induced presynaptic inhibition in the same cells was not changed. Given the time required for agonist treatment to reduce presynaptic inhibition, it is certainly possible that the loss of this effect reflects receptor downregulation rather than desensitiza-

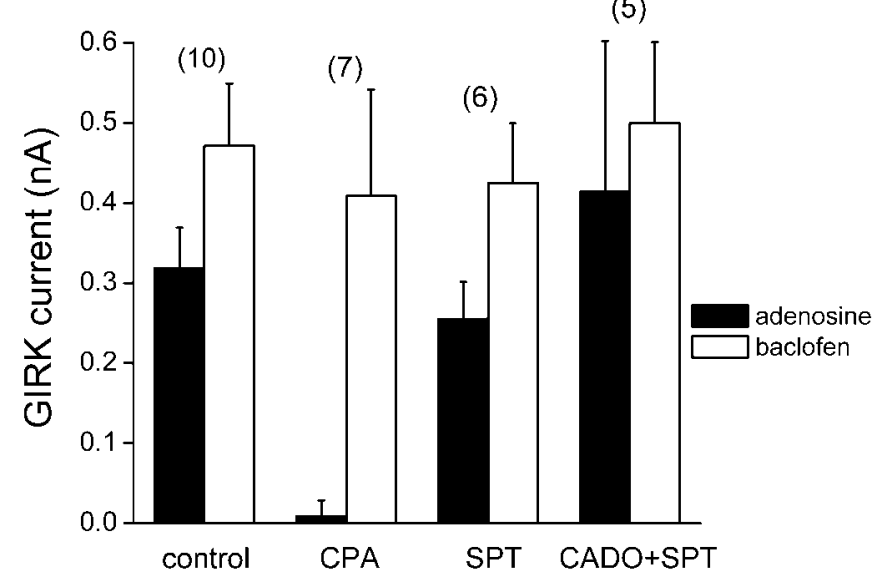

Figure 3. Desensitization of adenosine-induced activation of GIRK channels results from activation of A1Rs. Grouped data from neurons treated for $4 \mathrm{hr}$ with vehicle (control), the selective A1R agonist cyclopentyladenosine $(C P A)(10 \mu \mathrm{M})$, the A1R-preferring antagonist 8-sulfophenyltheophylline $(S P T)(100 \mu \mathrm{M})$, or CADO $(20 \mu \mathrm{M})$ plus SPT $(C A D O+S P T)$. GIRK currents were induced with adenosine $(100 \mu \mathrm{M})$ or baclofen $(50 \mu \mathrm{M})$ in the same cells. Homologous desensitization of postsynaptic A1R responses is mimicked by a selective agonist, and CADO-induced desensitization was blocked by SPT. Error bars represent the mean $\pm \mathrm{SE}$; the number of experiments $(n)$ is in parentheses.

tion or internalization of an unchanged number of receptors. However, to avoid implication of any mechanism, we will refer to this phenomenon as "desensitization," meaning simply the loss of responsiveness of some component of the signaling machinery.

We next performed a series of control experiments to verify that CADO-induced desensitization of presynaptic and postsynaptic adenosine responses was mediated by chronic activation of A1Rs. The results of these experiments for postsynaptic responses are shown in Figure 3. The effect of CADO was mimicked by $4 \mathrm{hr}$ treatment with the A1R agonist $\mathrm{N}^{6}$-cyclopentyladenosine (CPA) $(10 \mu \mathrm{M} ;-9 \pm 7 \mathrm{pA} ; n=7 ; p<0.01)$, and was blocked by the A1R antagonist 8-sulfophenyltheophylline (8-SPT) $(100 \mu \mathrm{M} ;-414 \pm$ $188 \mathrm{pA} ; n=5 ; p>0.05) ; 8$-SPT by itself had no effect. Similar experiments were performed for presynaptic inhibition. For example, presynaptic inhibition induced by $100 \mu \mathrm{M}$ adenosine was reduced to $20 \pm 5 \%$ after $48 \mathrm{hr}$ treatment with CPA $(n=5 ; p<$ 0.01 ), and CADO-induced desensitization was prevented or reversed by addition of DPCPX ( $1 \mu \mathrm{M}$; data not shown). These results suggest that desensitization at both sites is mediated by chronic activation of A1Rs, rather than a nonspecific effect of CADO.

Because presynaptic and postsynaptic A1R responses appeared to desensitize at different rates, we measured presynaptic inhibition and activation of GIRK channels by A1Rs and GABABRs after CADO exposures ranging from 1 to $360 \mathrm{hr}$. As shown in Figure 4, desensitization of the postsynaptic A1R response was essentially complete in $2 \mathrm{hr}$. In contrast, desensitization of the presynaptic A1R response began after a considerable lag $(\sim 12$ $\mathrm{hr}$ ) and was still incomplete after $48 \mathrm{hr}$. GABABR-mediated responses were never affected by CADO treatment. Both presynaptic and postsynaptic A1R-mediated responses recovered after either agonist washout (Fig. 4) or addition of DPCPX (1 $\mu \mathrm{M}$; data not shown). However, the time course of recovery from desensitization differed for the two responses. Postsynaptic A1R responses desensitized with $4 \mathrm{hr}$ of agonist treatment returned to control levels after being returned to agonist-free medium for $8 \mathrm{hr}$ 
A

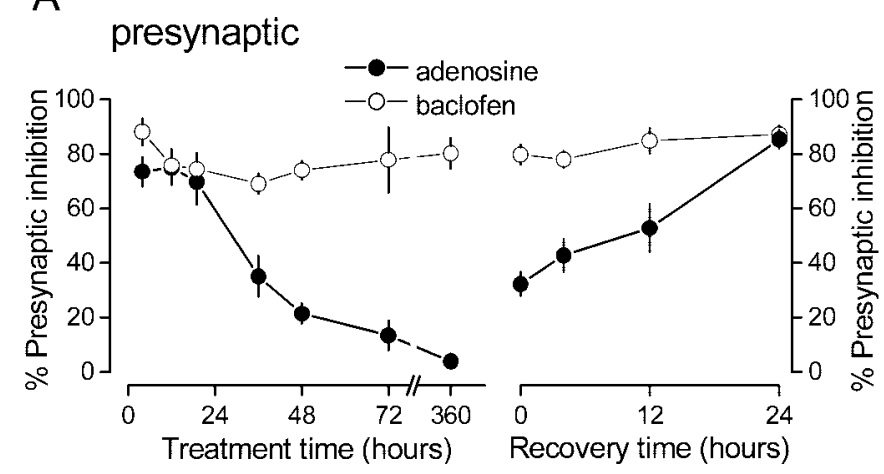

B

postsynaptic

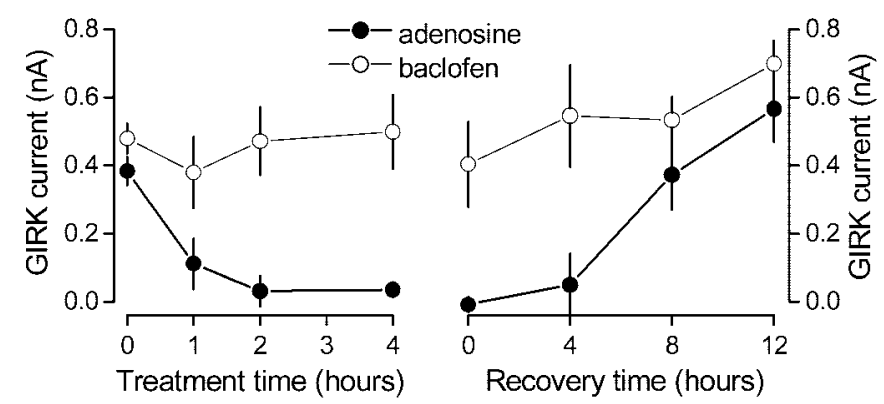

Figure 4. Presynaptic adenosine responses desensitize and recover from desensitization over the course of days, whereas postsynaptic adenosine responses desensitize and recover from desensitization over the course of hours. $A$, Presynaptic inhibition mediated by adenosine $(100 \mu \mathrm{M})$ and baclofen $(50 \mu \mathrm{M})$ in the same cells plotted as a function of time after 20 $\mu \mathrm{M}$ CADO treatment (left) and time after CADO removal after $48 \mathrm{hr}$ of CADO treatment (right). B, Postsynaptic GIRK current induced by adenosine and baclofen in the same cells plotted as a function of time after CADO treatment (left) and time after CADO removal after $4 \mathrm{hr}$ of CADO treatment (right). Each point represents the mean $\pm \mathrm{SE}$ of at least five experiments.

( $n=7 ; p=0.9$ compared with controls). In contrast, presynaptic A1R responses desensitized with $48 \mathrm{hr}$ of agonist treatment were only partially restored after $12 \mathrm{hr}$ of washing $(n=6$; $p<0.01)$. Recovery of presynaptic A1R responses was complete after $24 \mathrm{hr}$ of washing $(n=6 ; p=0.13)$ (Fig. 4). Taken together, these results suggest substantial differences in agonist-induced regulation of responses mediated by presynaptic and postsynaptic A1Rs.

Postsynaptic desensitization reflects a change in $A_{1}$ receptors rather than downstream signaling molecules

A reduction of postsynaptic adenosine-induced GIRK currents after $4 \mathrm{hr}$ A1R activation could reflect a change in the number or function of $A_{1}$ receptors, G-proteins, or GIRK channels. However, it is thought that postsynaptic A1Rs and GABABRs couple to a common population of GIRK channels in mature hippocampal neurons (Nicoll et al., 1990), because currents mediated by activation of these receptors are mutually occlusive (Sodickson and Bean, 1998). We repeated this experiment to determine whether A1Rs and GABABRs also couple to a common population of GIRK channels in cultured neonatal hippocampal neurons. As shown in Figure 5, GIRK currents evoked by saturating concentrations of adenosine and baclofen were occlusive rather than additive. The ratio of baclofen-induced current to that induced by combined application of adenosine and baclofen was $0.93 \pm 0.05(n=13)$, indicating that most of the GIRK channels
A

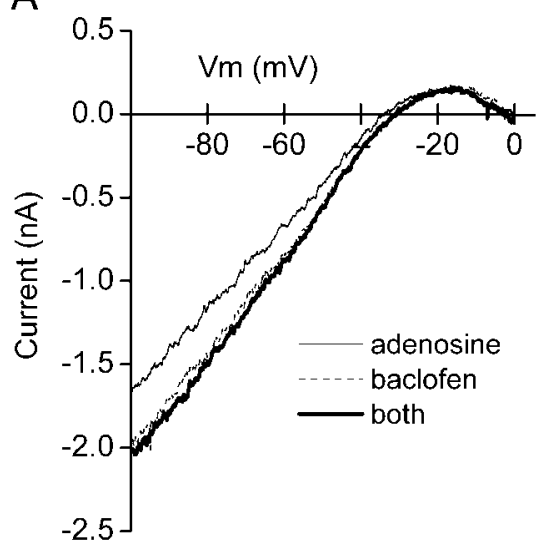

B

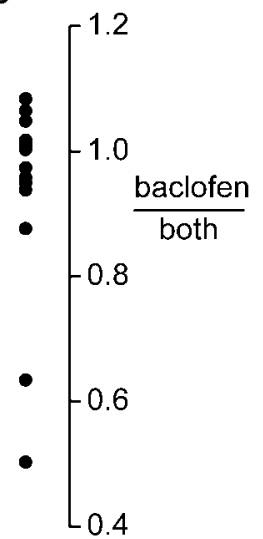

Figure 5. A1Rs and GABABRs activate a common population of GIRK channels in cultured hippocampal neurons. $A$, Leak-subtracted currents induced by adenosine $(100 \mu \mathrm{M})$, baclofen $(50 \mu \mathrm{M})$, and the combination of these two drugs (both) are plotted as a function of voltage and superimposed. Currents reverse polarity near the predicted $E_{\mathrm{K}^{+}}$of $-39 \mathrm{mV}$ (30 $\mathrm{mm}$ external $\mathrm{K}^{+}$) and rectify heavily at more positive potentials. The GIRK current induced by the combination of drugs was equal to that induced by baclofen alone, suggesting that A1Rs activate GIRK channels that can also be activated by GABABRs. $B$, The ratio of GIRK current evoked by baclofen to that evoked by the combination of baclofen and adenosine (both) is plotted for 13 cells. Most of the cells cluster near a ratio of 1 , similar to the example shown in $A$.

activated by A1Rs were also activated by GABABRs. Thus it is unlikely that the reduction of adenosine-induced GIRK currents after chronic CADO treatment reflects a change in these channels.

We next explored the possibility that A1R agonist treatment alters the activity or availability of postsynaptic G-proteins. This could produce a homologous desensitization such as we observed, provided GABABR-mediated responses were much less sensitive to such regulation (e.g., by coupling more efficiently to G-proteins). To test this hypothesis we constructed concentration-response curves for baclofen-induced GIRK currents with and without CADO treatment. If postsynaptic G-protein activity was in some way impaired by chronic A1R activation, we expected a rightward shift in this relationship. However, CADO treatment had no effect on the concentration-dependence of baclofen activation of GIRK channels; average $\mathrm{EC}_{50}$ values were $3.0 \mu \mathrm{M}(n \geq 6)$ and $3.7 \mu \mathrm{M}(n \geq 5)$ in vehicle- and CADO-treated neurons, respectively (Fig. 6). It should be emphasized that this experiment would not detect changes in G-protein function if A1Rs and GABABRs coupled to separate populations of PTXsensitive G-proteins. However, these results suggest that the diminished postsynaptic adenosine response after $4 \mathrm{hr}$ agonist treatment most likely reflects a change at the level of the A1Rs rather than a change in G-proteins or GIRK channels.

\section{Desensitization of A1R-mediated modulation of postsynaptic calcium channels}

Presynaptic inhibition mediated by A1Rs results from inhibition of presynaptic voltage-gated calcium channels. Therefore, regulation of presynaptic inhibition and activation of postsynaptic GIRK channels could differ either because of subcellular location or because the effector ion channels are different. To distinguish between these possibilities, we measured inhibition of whole-cell calcium currents by activation of postsynaptic A1Rs and GABABRs in CADO-treated and control neurons. Because such in- 


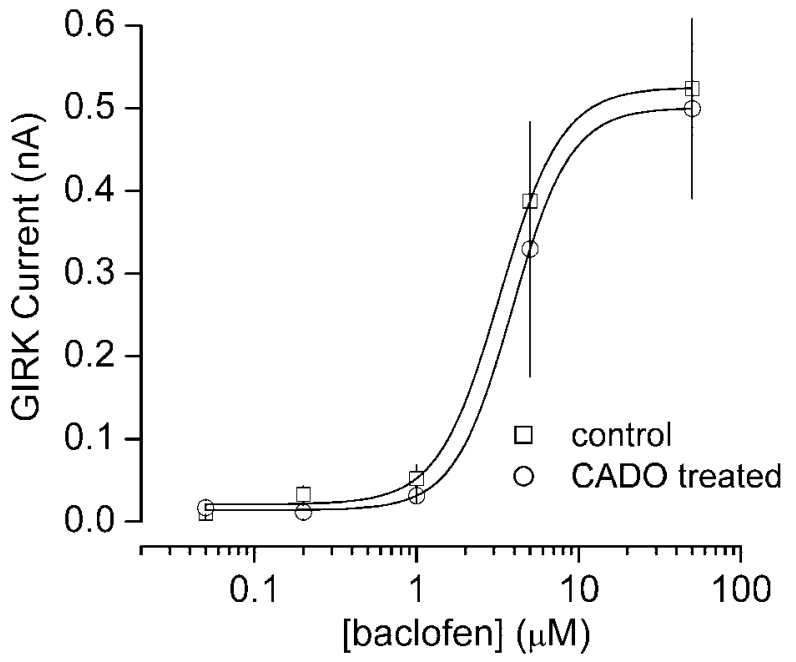

Figure 6. CADO treatment does not impair postsynaptic G-protein function. Concentration-response curves for baclofen-induced activation of GIRK current (at $-60 \mathrm{mV}, 30 \mathrm{~mm}$ external $\mathrm{K}^{+}$) are plotted from vehicle-treated control cells and CADO-treated $(20 \mu \mathrm{M}, 4 \mathrm{hr})$ cells. Baclofen potency was not changed by CADO treatment, indicating that postsynaptic G-protein activity was unaltered. All data points represent the mean $\pm \mathrm{SE}$ of at least five experiments. Concentration-response curves were fitted with the Hill equation.

hibition is mediated by somatodendritic receptors, we predicted that CADO treatment would produce a rapid homologous desensitization of A1R-mediated inhibition of postsynaptic voltagegated calcium channels. Using a Cs-based internal solution and an external solution designed to isolate calcium currents, neurons were held at $-80 \mathrm{mV}$ and stepped to $0 \mathrm{mV}$ for $40 \mathrm{msec}$. The currents evoked by this protocol (Fig. 7) were completely abolished by cadmium (100 $\mu \mathrm{M}$; data not shown) and were slow to activate and inactivate compared with currents evoked in electrotonically compact cells, indicating that voltage clamp in these complex neurons was imperfect. Nonetheless, in most cells voltage clamp was sufficient for us to observe robust reversible inhibition of calcium currents $\left(I_{\mathrm{Ca}}\right)$ (Fig. 7). In 16 control cells, adenosine $(50 \mu \mathrm{M})$ inhibited peak $I_{\mathrm{Ca}}$ by $21 \pm 2 \%$, and baclofen $(30 \mu \mathrm{M})$ inhibited peak $I_{\mathrm{Ca}}$ by $26 \pm 2 \%$. A paired $t$ test indicated that inhibition of $I_{\mathrm{Ca}}$ by baclofen was significantly greater than that by adenosine $(p<0.001)$. These values agree well with previous studies of calcium channel inhibition in cultured hippocampal neurons (Scholz and Miller, 1991a,b). In 14 neurons treated with $20 \mu \mathrm{M}$ CADO for 2-9 hr (average $6.9 \mathrm{hr}$ ), adenosine inhibited peak $I_{\mathrm{Ca}}$ by $11 \pm 1 \%$, and baclofen inhibited peak $I_{\mathrm{Ca}}$ by $24 \pm 1 \%$ (Fig. 7). Inhibition of $I_{\mathrm{Ca}}$ by adenosine in CADOtreated neurons was significantly less than that in control cells $(p<0.001)$, whereas inhibition by baclofen was unaltered $(p=$ 0.37). Desensitization of postsynaptic A1R-mediated inhibition of calcium channels was less complete $(\sim 50 \%)$ than desensitization of postsynaptic A1R-mediated activation of GIRK channels $(\sim 90 \%)$ after similar CADO treatment. However, desensitization of this response was maximal at this time, because CADO treatment for $24 \mathrm{hr}$ did not further reduce inhibition of $I_{\mathrm{Ca}}$ by adenosine $(12 \pm 3 \% ; n=5 ; p=0.70$ compared with cells treated for $2-9 \mathrm{hr}$ ). These results suggest that responses mediated by different effector molecules can desensitize to varying degrees in a single neuronal compartment (see Discussion). However, if inhibition of $I_{\mathrm{Ca}}$ in presynaptic terminals had desensitized to the same extent as we observed for somatodendritic $I_{\mathrm{Ca}}$, presynaptic
A

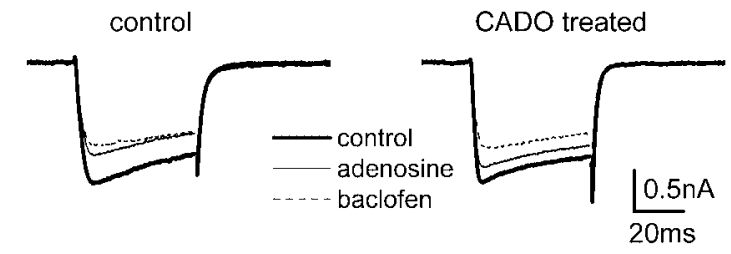

B

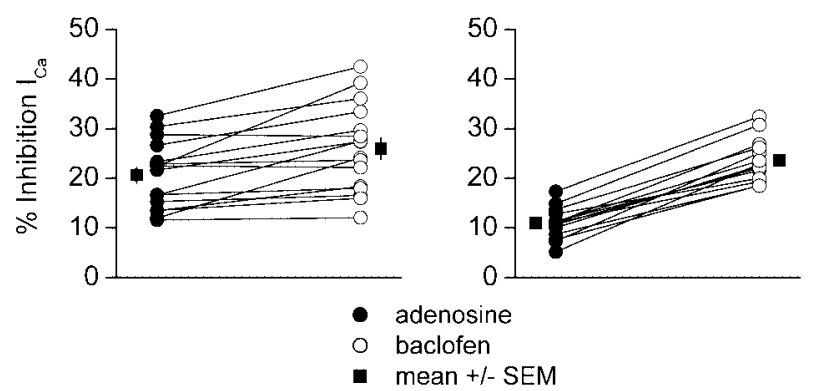

Figure 7. A1R-mediated inhibition of postsynaptic voltage-gated calcium channels also desensitizes rapidly. $A$, Examples of superimposed averaged calcium currents $\left(I_{\mathrm{Ca}}\right)$ evoked by step commands to $0 \mathrm{mV}$ recorded under control conditions, in the presence of $50 \mu \mathrm{M}$ adenosine, and in the presence of $30 \mu \mathrm{M}$ baclofen. $B$, Grouped data from such experiments. Adenosine and baclofen responses in individual cells are joined by lines; the mean $\pm \mathrm{SE}$ of all of these experiments is shown beside the individual points. In vehicle-treated (control) cells (left), adenosine and baclofen inhibit peak $I_{\mathrm{Ca}}$ by comparable amounts ( $21 \mathrm{vs} 26 \%$, respectively; $\left.n=16\right)$. In cells treated with $20 \mu \mathrm{M}$ CADO for 2-9 hr (right) (average $6.9 \mathrm{hr}$ ), inhibition of $I_{\mathrm{Ca}}$ by adenosine was substantially diminished (11 vs $24 \%$ for baclofen; $n=14$ ).

inhibition would have been substantially reduced. Thus we conclude that desensitization of neuronal A1Rs also differs for different subcellular compartments.

\section{Spare presynaptic A1Rs do not explain differential regulation}

One possible explanation for the apparent absence of desensitization of presynaptic A1Rs after brief agonist exposures is that a large receptor reserve exists at presynaptic terminals but not at postsynaptic sites. In this case inactivation of a large fraction of the receptors at both locations could spare maximal presynaptic inhibition induced by saturating concentrations of adenosine yet substantially decrease the postsynaptic response. We therefore constructed concentration-response curves in the presence of 6 $\mathrm{mm}$ external $\mathrm{K}^{+}$, which allowed us to measure presynaptic inhibition and activation of postsynaptic GIRK channels simultaneously in individual cells. These curves allowed us to compare activation of GIRK channels and presynaptic inhibition as functions of A1R occupancy. If a greater A1R reserve existed at presynaptic terminals, the concentration-response relationship for presynaptic inhibition in control cells should be shifted leftward compared with that for activation of GIRK channels, because a lower degree of receptor occupancy would be required to produce a maximal response. As shown in Figure 8, the concentration-response curve for A1R-mediated presynaptic inhibition in fact was shifted leftward compared with the curve for activation of postsynaptic GIRK channels. The $\mathrm{EC}_{50}$ for presynaptic inhibition was $0.42 \mu \mathrm{M}$, whereas that for activation of postsynaptic GIRK channels was $1.87 \mu \mathrm{M}(n \geq 6)$. In addition, A1R occupancy increased (as indicated by activation of substantial additional GIRK current) over a concentration range in which presynaptic inhibition was already nearly maximal $(2.5-25 \mu \mathrm{M})$. These results suggest that a receptor reserve indeed does exist for A1R- 


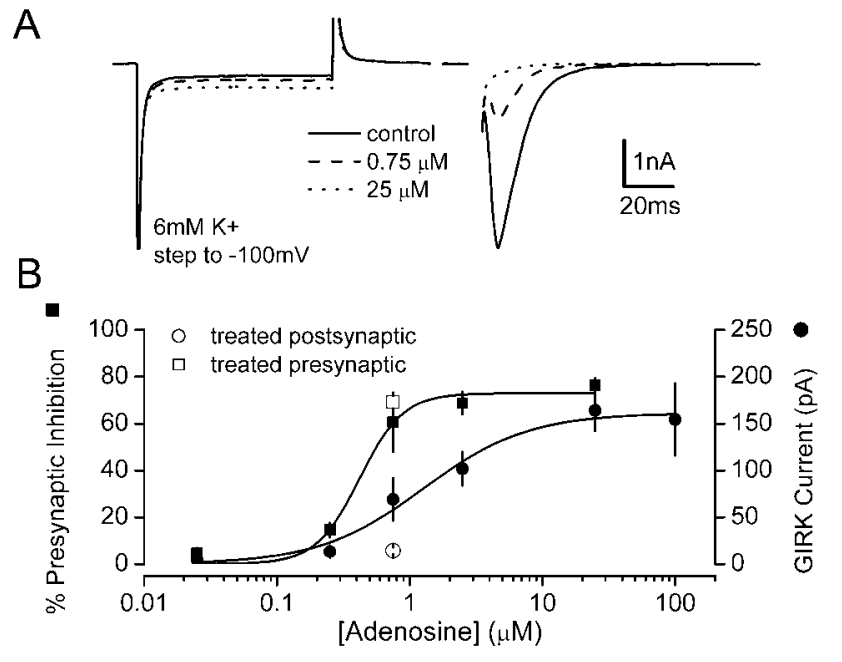

Figure 8. The concentration-response curves for presynaptic and postsynaptic adenosine effects overlap. $A$, Examples of superimposed averaged traces recorded in the presence of $6 \mathrm{~mm}$ external $\mathrm{K}^{+}$under control conditions and in the presence of 0.75 and $25 \mu \mathrm{M}$ adenosine. GIRK channel activity was indicated by the inward current response during steps to $-100 \mathrm{mV}$. Presynaptic inhibition was indicated by the decrease in EPSC amplitude evoked in the same cells. $B$, Concentrationresponse curves constructed from this type of experiment are shown superimposed. Concentration-response curves were fitted with the Hill equation. Two additional points at $0.75 \mu \mathrm{M}$ show presynaptic and postsynaptic responses in $4 \mathrm{hr}$ CADO-treated cells. All data points represent the mean \pm SE of at least 12 experiments, with the exception of the $100 \mu \mathrm{M}$ postsynaptic point that was recorded from a separate group of six cells. The overlap of presynaptic and postsynaptic concentration-response curves suggests that a decrease in receptor availability sufficient to produce a large decrease in the maximal postsynaptic response would produce a substantial decrease in the maximal presynaptic response.

mediated presynaptic inhibition, as suggested previously by studies of A1R-deficient mutant mice (Johansson et al., 2001). However, the degree of overlap of the two curves indicates that this receptor reserve cannot account for the difference in desensitization of presynaptic and postsynaptic A1R responses that we observed. If desensitization spared equal fractions of receptors at presynaptic and postsynaptic sites in CADO-treated cells, responses produced by occupation of all of these receptors (by a saturating concentration of adenosine) should be equivalent to responses produced by occupation of this same fraction of receptors in control cells (by a subsaturating concentration of adenosine). Thus desensitization of A1Rs sufficient to decrease maximal postsynaptic responses by $90 \%$ (the amount that we observed with 4 hr CADO treatment) would reduce maximal presynaptic inhibition to $<50 \%$ (Fig. 8). Because maximal presynaptic inhibition was unaffected by this treatment (Fig. 1), we conclude that chronic agonist application desensitized presynaptic and postsynaptic A1Rs at different rates.

The above results suggest that an A1R reserve is present at presynaptic terminals, but that it is not sufficiently large to account for the difference between desensitization of presynaptic and postsynaptic responses by $4 \mathrm{hr}$ CADO treatment. However, this treatment could have desensitized some presynaptic A1Rs but not enough to remove the receptor reserve and thus decrease the maximum response. To determine whether brief CADO treatment had any effect at all on A1R-mediated presynaptic inhibition, we constructed concentration-response curves after exposure to $\mathrm{CADO}$ for increasing time intervals. In the presence of a receptor reserve, desensitization of a fraction of presynaptic

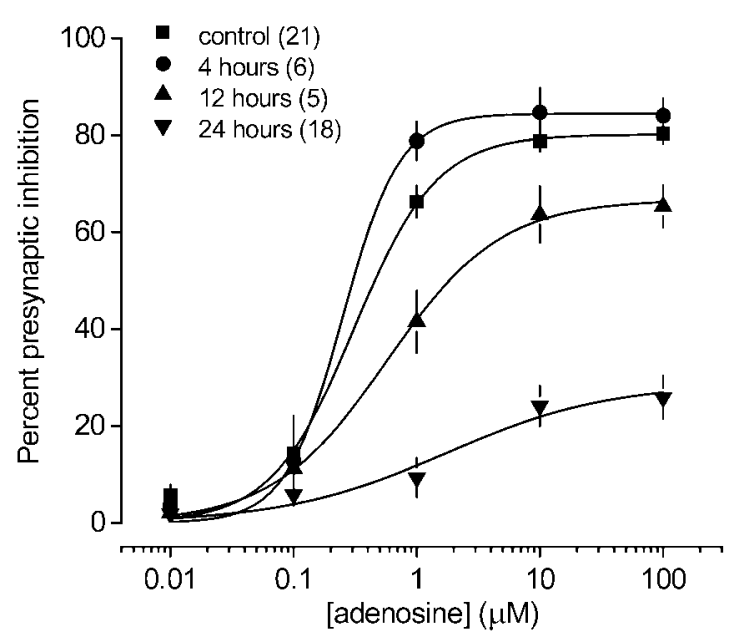

Figure 9. The absence of presynaptic A1R desensitization after $4 \mathrm{hr}$ agonist treatment is not caused by a presynaptic A1R reserve. Concentration-response curves for adenosine-induced presynaptic inhibition are plotted from vehicle-treated control cells and cells treated with CADO $(20 \mu \mathrm{M})$ for 4,12 , and $24 \mathrm{hr}$. Adenosine potency was not changed by $4 \mathrm{hr}$ CADO treatment, suggesting that the lack of desensitization of presynaptic responses to adenosine was not caused by spare presynaptic A1Rs. Adenosine potency was decreased after 12 and $24 \mathrm{hr}$ CADO treatment, as indicated by the rightward shift in the concentration-response curves. All data points represent the mean $\pm \mathrm{SE}$; the number of cells $(n)$ is in parentheses. Concentration-response curves were fitted with the Hill equation.

A1Rs would produce a rightward shift in the concentrationresponse relationship for this response, because a greater fraction of the remaining A1Rs would need to be occupied to produce the same effect. However, $4 \mathrm{hr}$ CADO treatment had no effect on the concentration dependence of adenosine-induced presynaptic inhibition; average $\mathrm{EC}_{50}$ values were $0.31 \mu \mathrm{M}(n=21)$ in vehicletreated neurons and $0.25 \mu \mathrm{M}$ in neurons treated with CADO for $4 \mathrm{hr}(n=6)$ (Fig. 9). This result was confirmed in a separate set of neurons $(n=12)$ in which presynaptic inhibition produced by $0.75 \mu \mathrm{M}$ adenosine (a value just above the presynaptic $\mathrm{EC}_{50}$ ) was unaffected by $2-4 \mathrm{hr}$ CADO treatment ( $p>0.05$ compared with untreated cells), whereas GIRK currents in the same cells were virtually abolished (Fig. 8, open symbols). These results indicate that this duration of agonist exposure did not disable a significant fraction of presynaptic A1Rs. In contrast, average $\mathrm{EC}_{50}$ values were 0.57 and $1.73 \mu \mathrm{M}(n \geq 6)$ in neurons treated with CADO for 12 and $24 \mathrm{hr}$, respectively (Fig. 9). The rightward shifts of these concentration-response curves support the idea that an A1R reserve at presynaptic terminals is eventually removed during long-term ( $>4 \mathrm{hr})$ agonist treatment.

\section{DISCUSSION}

The results shown here demonstrate that responses mediated by presynaptic and postsynaptic A1Rs desensitize at markedly different rates. This difference does not appear to reflect a difference in receptor density (receptor reserve) at presynaptic and postsynaptic sites, or a difference in downstream signaling components, and thus probably results from a difference in the mechanisms that regulate receptor function. These results complement previous studies, which have shown that chronic in vivo administration of A1R agonists or antagonists regulates the function of these receptors in the hippocampus (Lupica et al., 1991; Fernandez et al., 1996).

The loss of postsynaptic adenosine responses after $4 \mathrm{hr}$ of 
agonist treatment was not accompanied by a change in the sensitivity of the same GIRK channels to activation of GABABRs. This suggests that neither postsynaptic GIRK channels nor postsynaptic G-proteins were adversely affected by prolonged activation of A1Rs, at least within the limits of sensitivity of our assay. However, the latter conclusion is limited by the assumption that A1Rs and GABABRs couple to a common population of PTX-sensitive G-proteins. We are unaware of any direct evidence that either supports or refutes this assumption; thus it is possible that prolonged A1R activation in some way impairs a population of G-proteins that couples to these receptors but not GABABRs. A change of this type could also explain homologous desensitization of calcium channel inhibition. However, if a change in G-protein function is responsible for the rapid loss of postsynaptic adenosine responses, our results suggest that presynaptic G-proteins would have to be regulated differently, because inhibition of presynaptic calcium channels was not similarly impaired.

Although activation of postsynaptic GIRK channels and inhibition of postsynaptic $I_{\mathrm{Ca}}$ both desensitized more rapidly than presynaptic inhibition, it was notable that activation of GIRK channels was nearly abolished after a few hours of agonist exposure, whereas inhibition of $I_{\mathrm{Ca}}$ was reduced to only half of the control level, even after $24 \mathrm{hr}$ of agonist exposure. What might account for this difference? One possibility is that different populations of postsynaptic A1Rs mediate these two responses and that the receptors that couple to calcium channels desensitize incompletely. Another, perhaps more likely possibility is that the difference results from different sensitivity of these ion channels to G-protein $\beta \gamma$ dimers. Both channels are affected by binding $\beta \gamma$ dimers (Logothetis et al., 1987; Ikeda, 1996), but GIRK channels apparently need to bind more than one dimer for activation (Corey and Clapham, 2001), whereas calcium channels are apparently inhibited by binding of single dimers (De Waard et al., 1997). This difference, together with possible differences in affinity, efficacy, and spatial arrangement, could make GIRK channels relatively insensitive to free $\beta \gamma$ subunits. Such a difference could partially account for the receptor reserve at presynaptic terminals, because presynaptic inhibition is mediated by inhibition of calcium channels. In this case residual postsynaptic receptor activity could be unable to liberate sufficient $\beta \gamma$ dimers to activate most GIRK channels, whereas at the same time a significant fraction of calcium channels could be inhibited. Simultaneous recordings of these two responses in individual cells could give some idea as to the relative sensitivity of each to G-protein activation. Additional experiments will be required to determine the basis of this apparent dependence of desensitization on effector mechanism.

One possible explanation for the lack of apparent desensitization of A1R-mediated presynaptic inhibition after $4 \mathrm{hr}$ CADO treatment is that there are spare receptors for this response. In fact, our results as well as those of previous studies (Johansson et al., 2001) indicate that an A1R reserve does exist at hippocampal presynaptic terminals. However, three pieces of evidence suggest that this receptor reserve alone cannot explain the differences that we observed between presynaptic and postsynaptic A1Rmediated responses. First, concentration-response curves for presynaptic and postsynaptic responses overlap to such an extent that no decrease in receptor activity could produce a $\sim 90 \%$ decrease in GIRK activation without changing maximal presynaptic inhibition, much less presynaptic inhibition produced by a lower concentration of adenosine (Fig. 8). Second, no change in the concentration-response relationship was observed for presynaptic inhibition until CADO was present for $12 \mathrm{hr}$ (Fig. 9). This observation was confirmed using a concentration of adenosine (750 nM) just above the $\mathrm{EC}_{50}(300-400 \mathrm{nM})$, a point that should be quite sensitive to changes in the total number of functional receptors. Third, if all else were equal at presynaptic and postsynaptic sites with the exception of a receptor reserve, we would have expected that desensitization of maximal presynaptic inhibition would have been delayed (as it was), but that it would have progressed rapidly (in a few hours) after the receptor reserve was depleted. As shown in Figure 4, this was not the case. It is unlikely that rapid replenishment of presynaptic A1Rs explains the slow development of presynaptic desensitization, because this would predict rapid recovery of presynaptic inhibition after agonist removal or addition of antagonist (compare Fig. 4). Taken together, these results suggest that A1Rs are regulated differently by agonist exposure at presynaptic and postsynaptic sites in these neurons.

The molecular mechanisms that regulate presynaptic and postsynaptic A1Rs and their downstream effectors are unknown; therefore, we can only speculate as to why A1R-mediated responses desensitize differently in these two compartments. Many GPCRs are desensitized via a canonical mechanism whereby active receptors are phosphorylated by a GRK, phosphorylated receptors bind an arrestin, and arrestin-bound receptors are internalized. Studies of A1R desensitization in vitro and in other types of cells have shown that A1Rs can be phosphorylated (albeit weakly), uncoupled from G-proteins, and are internalized in an agonist-dependent manner (Ramkumar et al., 1993; Ciruela et al., 1997; Nie et al., 1997; Hettinger et al., 1998; Olah and Stiles, 2000). In striatal slices and cultured cerebellar granule neurons, A1R-mediated inhibition of adenylate cyclase can desensitize (incompletely) in $<2 \mathrm{hr}$. This desensitization apparently results from uncoupling of A1Rs and G-proteins, because total A1R density (assessed by radioligand binding) is unchanged (Abbracchio et al., 1992; Vendite et al., 1998). A1R density has been shown to decrease in response to agonist treatment in granule neurons, but this downregulation occurred over the course of 48 hr (Hettinger-Smith et al., 1996; Hettinger et al., 1998). It is therefore tempting to speculate that the relatively rapid loss of postsynaptic responses results from a true "desensitization" or internalization mechanism, whereas the slower loss of presynaptic responses results from receptor downregulation. The relatively slow recovery of presynaptic inhibition after agonist removal is consistent with this model. Future experiments will be directed toward determining the mechanisms of agonist-induced regulation of A1Rs in presynaptic and postsynaptic compartments. It will also be interesting to determine whether a difference in desensitization of presynaptic and postsynaptic receptors similar to that which we have shown for A1Rs in hippocampal neurons is observed for other GPCRs in other types of neurons and in other types of polarized cells (Sitaraman et al., 2000). For example, chronic activation of opiate receptors produces well characterized changes in presynaptic and postsynaptic function in various brain regions (Christie et al., 1987; Bonci and Williams, 1997; Williams et al., 2001), but desensitization of presynaptic and postsynaptic opiate receptors has not been compared in a single cell.

These findings may have implications for the complex processes of drug tolerance and drug dependence. Because GPCR desensitization is thought to underlie some aspects of nonassociative drug tolerance (Bohn et al., 2000), it is possible that differential 
desensitization of presynaptic and postsynaptic receptors can explain some instances in which tolerance to a given effect of a drug develops at a different rate than tolerance to other effects. Drug dependence may result from cellular adaptations that occur in response to persistent GPCR signaling (Nestler, 2001; Williams et al., 2001), which in turn could depend on slow or incomplete desensitization (Whistler and von Zastrow, 1998). The results presented here suggest that subcellular location may be one factor that influences the rate of GPCR desensitization and thus the propensity of a population of receptors to mediate the development of tolerance and dependence.

\section{REFERENCES}

Abbracchio MP, Fogliatto G, Paoletti AM, Rovati GE, Cattabeni F (1992) Prolonged in vitro exposure of rat brain slices to adenosine analogues: selective desensitization of adenosine A1 but not A2 receptors. Eur J Pharmacol 227:317-324.

Bekkers JM, Stevens CF (1991) Excitatory and inhibitory autaptic currents in isolated hippocampal neurons maintained in cell culture. Proc Natl Acad Sci USA 88:7834-7838.

Benovic JL, Strasser RH, Caron MG, Lefkowitz RJ (1986) Betaadrenergic receptor kinase: identification of a novel protein kinase that phosphorylates the agonist-occupied form of the receptor. Proc Natl Acad Sci USA 83:2797-2801.

Bohn LM, Gainetdinov RR, Lin FT, Lefkowitz RJ, Caron MG (2000) Mu-opioid receptor desensitization by beta-arrestin-2 determines morphine tolerance but not dependence. Nature 408:720-723.

Bonci A, Williams JT (1997) Increased probability of GABA release during withdrawal from morphine. J Neurosci 17:796-803.

Carman CV, Benovic JL (1998) G-protein-coupled receptors: turn-ons and turn-offs. Curr Opin Neurobiol 8:335-344.

Christie MJ, Williams JT, North RA (1987) Cellular mechanisms of opioid tolerance: studies in single brain neurons. Mol Pharmacol 32:633-638.

Ciruela F, Saura C, Canela EI, Mallol J, Lluis C, Franco R (1997) Ligand-induced phosphorylation, clustering, and desensitization of A1 adenosine receptors. Mol Pharmacol 52:788-797.

Corey S, Clapham DE (2001) The stoichiometry of G $\beta \gamma$ binding to G-protein-regulated inwardly rectifying $\mathrm{K}+$ channels (GIRKs). J Biol Chem 276:11409-11413.

De Waard M, Liu H, Walker D, Scott VE, Gurnett CA, Campbell KP (1997) Direct binding of G-protein betagamma complex to voltagedependent calcium channels. Nature 385:446-450.

Dunwiddie TV, Haas HL (1985) Adenosine increases synaptic facilitation in the in vitro rat hippocampus: evidence for a presynaptic site of action. J Physiol (Lond) 369:365-377.

Ehrengruber MU, Lanzrein M, Xu Y, Jasek MC, Kantor DB, Schuman EM, Lester HA, Davidson N (1998) Recombinant adenovirusmediated expression in nervous system of genes coding for ion channels and other molecules involved in synaptic function. Methods Enzymol 293:483-503.

Ferguson SS (2001) Evolving concepts in G protein-coupled receptor endocytosis: the role in receptor desensitization and signaling. Pharmacol Rev 53:1-24.

Ferguson SS, Caron MG (1998) G protein-coupled receptor adaptation mechanisms. Semin Cell Dev Biol 9:119-127.

Fernandez M, Svenningsson P, Fredholm BB (1996) Adaptive changes in adenosine receptors following long-term treatment with the adenosine receptor agonist R-phenylisopropyl adenosine. Life Sci 58:769-776.

Hettinger BD, Leid M, Murray TF (1998) Cyclopentyladenosineinduced homologous down-regulation of A1 adenosine receptors (A1AR) in intact neurons is accompanied by receptor sequestration but not a reduction in A1AR mRNA expression or G protein alpha-subunit content. J Neurochem 71:221-230.

Hettinger-Smith BD, Leid M, Murray TF (1996) Chronic exposure to adenosine receptor agonists and antagonists reciprocally regulates the A1 adenosine receptor-adenylyl cyclase system in cerebellar granule cells. J Neurochem 67:1921-1930.

Ikeda SR (1996) Voltage-dependent modulation of N-type calcium channels by G-protein beta gamma subunits. Nature 380:255-258.

Jan LY, Jan YN (1997) Voltage-gated and inwardly rectifying potassium channels. J Physiol (Lond) 505:267-282.

Johansson B, Halldner L, Dunwiddie TV, Masino SA, Poelchen W,
Gimenez-Llort L, Escorihuela RM, Fernandez-Teruel A, WiesenfeldHallin Z, Xu XJ, Hardemark A, Betsholtz C, Herlenius E, Fredholm BB (2001) Hyperalgesia, anxiety, decreased hypoxic neuroprotection in mice lacking the adenosine A1 receptor. Proc Natl Acad Sci USA 98:9407-9412.

Jolimay N, Franck L, Langlois X, Hamon M, Darmon M (2000) Dominant role of the cytosolic C-terminal domain of the rat 5-HT1B receptor in axonal-apical targeting. J Neurosci 20:9111-9118.

Lefkowitz RJ (1998) G protein-coupled receptors. III. New roles for receptor kinases and beta-arrestins in receptor signaling and desensitization. J Biol Chem 273:18677-18680.

Logothetis DE, Kurachi Y, Galper J, Neer EJ, Clapham DE (1987) The beta gamma subunits of GTP-binding proteins activate the muscarinic $\mathrm{K}+$ channel in heart. Nature 325:321-326.

Lohse MJ, Benovic JL, Codina J, Caron MG, Lefkowitz RJ (1990) beta-Arrestin: a protein that regulates beta-adrenergic receptor function. Science 248:1547-1550.

Lupica CR, Jarvis MF, Berman RF (1991) Chronic theophylline treatment in vivo increases high affinity adenosine A1 receptor binding and sensitivity to exogenous adenosine in the in vitro hippocampal slice. Brain Res 542:55-62.

Nestler EJ (2001) Molecular basis of long-term plasticity underlying addiction. Nat Rev Neurosci 2:119-128.

Nicoll RA, Malenka RC, Kauer JA (1990) Functional comparison of neurotransmitter receptor subtypes in mammalian central nervous system. Physiol Rev 70:513-565.

Nie Z, Mei Y, Ramkumar V (1997) Short term desensitization of the A1 adenosine receptors in DDT1MF-2 cells. Mol Pharmacol 52:456-464.

Olah ME, Stiles GL (2000) The role of receptor structure in determining adenosine receptor activity. Pharmacol Ther 85:55-75.

Pitcher JA, Freedman NJ, Lefkowitz RJ (1998) G protein-coupled receptor kinases. Annu Rev Biochem 67:653-692.

Proctor WR, Dunwiddie TV (1987) Pre- and postsynaptic actions of adenosine in the in vitro rat hippocampus. Brain Res 426:187-190.

Ramkumar V, Kwatra M, Benovic JL, Stilesa GL [corrected to Stiles GL] (1993) Functional consequences of A1 adenosine-receptor phosphorylation by the beta-adrenergic receptor kinase. Biochim Biophys Acta 1179:89-97.

Scholz KP, Miller RJ (1991a) Analysis of adenosine actions on Ca2+ currents and synaptic transmission in cultured rat hippocampal pyramidal neurones. J Physiol (Lond) 435:373-393.

Scholz KP, Miller RJ (1991b) GABAB receptor-mediated inhibition of $\mathrm{Ca} 2+$ currents and synaptic transmission in cultured rat hippocampal neurones. J Physiol (Lond) 444:669-686.

Segal MM, Furshpan EJ (1990) Epileptiform activity in microcultures containing small numbers of hippocampal neurons. J Neurophysiol 64:1390-1399.

Sitaraman SV, Si-Tahar M, Merlin D, Strohmeier GR, Madara JL (2000) Polarity of $\mathrm{A} 2 \mathrm{~b}$ adenosine receptor expression determines characteristics of receptor desensitization. Am J Physiol Cell Physiol 278:C1230-C1236.

Sodickson DL, Bean BP (1998) Neurotransmitter activation of inwardly rectifying potassium current in dissociated hippocampal CA3 neurons: interactions among multiple receptors. J Neurosci 18:8153-8162.

Stowell JN, Craig AM (1999) Axon/dendrite targeting of metabotropic glutamate receptors by their cytoplasmic carboxy-terminal domains. Neuron 22:525-536.

Thompson SM, Gahwiler BH (1992) Comparison of the actions of baclofen at pre- and postsynaptic receptors in the rat hippocampus in vitro. J Physiol (Lond) 451:329-345.

Thompson SM, Haas HL, Gahwiler BH (1992) Comparison of the actions of adenosine at pre- and postsynaptic receptors in the rat hippocampus in vitro. J Physiol (Lond) 451:347-363.

Thompson SM, Capogna M, Scanziani M (1993) Presynaptic inhibition in the hippocampus. Trends Neurosci 16:222-227.

Tsao P, Cao T, von Zastrow M (2001) Role of endocytosis in mediating downregulation of G-protein-coupled receptors. Trends Pharmacol Sci 22:91-96.

Vendite D, Sanz JM, Lopez-Alanon DM, Vacas J, Andres A, Ros M (1998) Desensitization of adenosine A1 receptor-mediated inhibition of adenylyl cyclase in cerebellar granule cells. Neurochem Res 23:211-218

Whistler JL, von Zastrow M (1998) Morphine-activated opioid receptors elude desensitization by beta- arrestin. Proc Natl Acad Sci USA 95:9914-9919.

Williams JT, Christie MJ, Manzoni O (2001) Cellular and synaptic adaptations mediating opioid dependence. Physiol Rev 81:299-343. 